\title{
Publication Rates and Citation Analysis of Oral and Poster Presentations at the First Congress of the Society of Urological Surgery in Turkiye
}

\author{
Ürolojik Cerrahi Derneği Kongresi'ndeki Poster ve Sözlü Sunumların Yayına Dönüşme Oranı \\ ve Atıf Analizi
}

\author{
Mustafa Yüksel', Kaan Karamık², Tümay İpekçi', Hakan AnıI², Ahmet Tunçkıran ${ }^{3}$ \\ ${ }^{1}$ Balıkesir State Hospital, Clinic of Urology, Balıkesir, Turkiye \\ ${ }^{2}$ University of Health Sciences, Antalya Training and Research Hospital, Clinic of Urology, Antalya, Turkiye \\ ${ }^{3}$ Başkent University Faculty of Medicine, Alanya Application and Research Center, Department of Urology, Antalya, Turkiye
}

\section{What's known on the subject? and What does the study add?}

Due to the strict and challenging process in peer review journals, only a limited number of publications with true scientific value find a place in these journals. As a result, the publication rates for poster and oral presentations have become an important parameter in evaluating the importance and prestige of a congress. This study, for the first time, investigated the quality of the presentations at the $1^{\text {st }}$ Congress of the Society of Urological Surgery in Turkiye held in 2012.

\begin{abstract}
Objective: Publications of congress presentations (oral/poster) contribute to the literature by creating new information. In this study, we examined the publication rate of poster and oral presentations at the $1^{\text {st }}$ Congress of the Society of Urological Surgery in Turkiye held in 2012.

Materials and Methods: We investigated the congress booklet belonging to the $1^{\text {st }}$ Congress of the Society of Urological Surgery in Turkiye held in 3-7 October 2012. We investigated the publication rates of 176 poster and 103 oral presentations under the headings of uro-oncology, andrology, pediatric urology, endourology, transplantation, continence and other by searching the PubMed and Science Citation Index Expanded (SCl-E) databases.

Results: Of the 176 poster and 103 oral presentations, 79 (28.3\%) were subsequently published. The publication rate in journals included in the SCl-E was $24.3 \%$. While $33 \%$ of oral presentations were published, $25.5 \%$ of poster presentations became publications and this difference was not found to be statistically significant $(p=0.48)$. The mean duration from presentation to publication was 21.1 months.

Conclusion: The publication rate of presentations at the $1^{\text {st }}$ Congress of the Society of Urological Surgery in Turkiye was higher than in most national congresses in different disciplines, but lower than many international congresses in the field of urology. Future studies investigating congress data from several consecutive years will provide clearer results.
\end{abstract}

Keywords: Citation, Poster, Oral, Presentation, Publication

Öz

Amaç: Poster ve sözlü sunumlarının yayın haline dönüşmeleri, yeni bilgi oluşmasını sağlayarak literatüre de katkı sağlamaktadır. Biz bu çalışmamızda Ürolojik Cerrahi Derneği'nin 2012 yılında yaptığı ilk kongresindeki poster ve sözlü sunumların yayınlaşma oranlarına bakarak ülkemizdeki durumu incelemek istedik. Gereç ve Yöntem: Ürolojik Cerrahi Derneği'nin 3-7 Ekim 2012 tarihinde gerçekleştirmiş olduğu 1. Ulusal Ürolojik Cerrahi Kongresi'nin kongre kitapçığı incelendi. Üroonkoloji, androloji, çocuk ürolojisi, endorüroloji, transplantasyon, kontinans ve diğer başlıkları altında yapılmış olan 176 poster sunumu ve 103 sözlü sunumun yayına dönüşme durumu internet üzerinden PubMed ve Science Citation Index Expanded (SCI-E) veri tabanları taranarak araştırıldı.

Correspondence: Mustafa Yüksel MD, Balıkesir State Hospital, Clinic of Urology, Balıkesir, Turkiye

Phone: +90 5416584098 E-mail: drmustafayuksel@outlook.com ORCID-ID: orcid.org/0000-0002-2681-1245

Received: 18.06 .2017

Accepted: 26.12 .2017

Cite this article as: Yüksel M, Karamık K, İpekçi T, Anıl H, Tunçkıran A. Publication Rates and Citation Analysis of Oral and Poster Presentations at the First

Congress of the Society of Urological Surgery in Turkiye. J Urol Surg 2018;5(1):12-16.

๑Copyright 2018 by the Association of Urological Surgery / Journal of Urological Surgery published by Galenos Publishing House. 
Bulgular: İncelenen 176 poster sunumu ve 103 sözlü sunumun 79'u (\%28,3) yayına dönüşmüştür. Sunumların SCI-E kapsamındaki dergilerde yayınlanma oranının ise \%24,3 olduğu görülmüştür. Sözlü sunumların \%33'ü yayına dönüşürken, poster sunumlarının \%25,5'i yayına dönüşmüştür ve bu fark istatistiksel olarak anlamlı bulunmamıştır $(p=0,48)$. Yayınlar sunumdan ortalama 21,1 ay sonra basılmıştır.

Sonuç: 1. Ürolojik Cerrahi Kongresi'ndeki sunumların yayınlaşma oranı farklı disiplinlerdeki ulusal kongrelerin çoğundan yüksek, üroloji alanındaki büyük uluslararası kongrelerden düşük bulunmuştur. İleride yapılacak, ardışık birkaç senelik kongrenin verilerini inceleyecek bir çalışma ile daha net sonuçlara ulaşılabilir.

Anahtar Kelimeler: Atıf, Poster, Sözlü, Sunum, Yayın

\section{Introduction}

Congresses organized by associations aim to communicate the latest developments in science to participants. Additionally, an aim of congresses is to contribute to the creation of new information by poster and oral presentations. While presentation of findings in poster and oral presentations to inform participants forms the first stage of information production, transforming these presentations into publications to contribute to the literature forms the second stage.

Due to the strict and challenging process in peer review journals, only a limited number of publications with true scientific value find a place in these journals (1). As a result, publication rates of poster and oral presentations have become an important parameter in evaluating the importance and prestige of a congress (2).

When the publication rates of presentations at international congresses in the field of urology are investigated, 47\% of presentations at the European Society for Pediatric Urology (ESPU) from 2003-2010 (3), 29.8\% of presentations at the Urological Society of Australia and New Zealand Annual Scientific Meeting from 2005-2009 (4), 44\% of presentations at the American Urological Association Annual Meeting from 2002-2003 (5), 61.6\% of presentations at the International Continence Society Meeting 2003 (6) and 47.3\% of presentations at the European Association of Urology (EAU) in 2000 and 2001 (7) were subsequently published.

In this study, we investigated the publication rate of poster and oral presentations at the $1^{\text {st }}$ Congress of the Society of Urological Surgery in Turkiye held in 2012 to investigate.

\section{Materials and Methods}

We analyzed the congress booklet belonging to the $1^{\text {st }}$ Congress of the Society of Urological Surgery in Turkiye held in 3-7 October 2012. We investigated the publication rate of 176 poster and 103 oral presentations under the headings of uro-oncology, andrology, pediatric urology, endourology, transplantation, continence and other by searching the PubMed and Science Citation Index Expanded (SCl-E) databases. The presentations were classified as retrospective, prospective, laboratory studies and case reports. Presentations definitely transformed into publications were assessed. Institutions and the journal of publications, the impact factor of the journal and numbers of citations obtained were noted. Fourteen publications printed before the date of the congress were not evaluated. The date of publication of the presentations was noted and the time to publication was calculated. Publications in the PubMed database and in the SCl-E were assessed separately. The publication rates of presentations in each of the topic sub-headings were calculated. The publication rates of oral presentations and poster presentations and those of prospective, retrospective and laboratory studies were compared.

Our study was completed in accordance with the Declaration of Helsinki, with no ethics committee permission necessary for screening of publications.

\section{Statistical Analysis}

The Statistical Package for Social Sciences (SPSS Inc., Chicago, Illinois, USA) 16.0 program was used for analysis. Descriptive analysis was used to determine frequency and categorical variables were analyzed using the chi-square test. A $p$ value of less than 0.05 was considered statistically significant.

\section{Results}

Of the 176 poster and 103 oral presentations investigated, 79 $(28.3 \%)$ were subsequently published. The publication rate of all presentations in journals included in SCI-E was 24.3\%. While $33 \%$ of oral presentations were published, $25.5 \%$ of poster presentations became publications and this difference was not found to be statistically significant $(p=0.48)$. The distribution and publication rates according to topic are shown in Table 1.

The publication rates according to study type for presentations excluding case reports are shown in Table 2.

The mean length of time between presentation and publication was 21.1 months. Of 79 publications, 36 were multi-center studies, with 24 produced by centers in the 3 largest cities of Turkiye (Ankara, İstanbul, İzmir), while 19 publications were produced by centers outside the 3 largest cities. The mean impact factor of journals was 1.55 (0.05-14.97). Fifty-five publications were in urology journals, while 24 were in nonurology journals. The mean citation number per publication was 5.65 (0-29). Presentations were published in 40 different SCI-E 
Table 1. Publication rates based on presentation topics

\begin{tabular}{llllll}
\hline Topic & $\begin{array}{l}\text { Number of poster } \\
\text { presentations }\end{array}$ & $\begin{array}{l}\text { Number of oral } \\
\text { presentations }\end{array}$ & $\begin{array}{l}\text { Number of publication } \\
\text { in SCI-E journals }\end{array}$ & $\begin{array}{l}\text { Total number of } \\
\text { publications }\end{array}$ \\
\hline Uro-oncology & 79 & 38 & 23 & 29 & $\begin{array}{l}\text { Total publication } \\
\text { rate }\end{array}$ \\
Andrology & 14 & 14 & 10 & 11 & $24.7 \%$ \\
Pediatric urology & 31 & 16 & 12 & 13 & 16 \\
Endourology & 32 & 16 & 14 & 1 & $39.2 \%$ \\
Transplantation & 3 & 4 & 1 & 7 & $33.3 \%$ \\
Continence & 14 & 12 & 6 & $27.6 \%$ \\
Other & 3 & 3 & 2 & $26.9 \%$ \\
\hline
\end{tabular}

SCI-E: Science Citation Index Expanded

Table 2. Publication rates according to type of study

\begin{tabular}{llll}
\hline Study type & $\begin{array}{l}\text { Number of } \\
\text { presentations }\end{array}$ & $\begin{array}{l}\text { Number of } \\
\text { publications (\%) }\end{array}$ & $\mathbf{p}^{*}$ \\
\hline Retrospective & 155 & $38(24.5 \%)$ & \\
Prospective & 76 & $24(31.5 \%)$ & 0.172 \\
Laboratory & 30 & $12(40 \%)$ & \\
\hline${ }^{*}$ Chi-square test & & & \\
\hline
\end{tabular}

Table 3. Science Citation Index Expanded indexed journals with most publications

\begin{tabular}{lll}
\hline Journal name & Number of publications & Impact factor \\
\hline Urol Int & 5 & 1.313 \\
Int Braz J Urol & 5 & 0.871 \\
Urol J & 5 & 0.737 \\
J Urol & 4 & 4.7 \\
J Pediatr Urol & 4 & 1.17 \\
Urology & 3 & 2.187 \\
Actas Urol Esp & 3 & 0.964 \\
\hline
\end{tabular}

Urol Int: Urologia Internationalis, Int Braz Urol: International Brazilian Journal of Urology, Urol J: Urology Journal, J Urol: Journal of Urology, J Pediatr Urol: Journal of Pediatric Urology, Actas Urol Esp: Actas Urológicas Españolas

journals. 47 (59.4\%) publications were published in journals with impact factor above 1 . The SCl-E-indexed journals with the most publications are listed in Table 3.

\section{Discussion}

This study, for the first time, investigated the quality of presentations at the $1^{\text {st }}$ Congress of the Society of Urological Surgery in Turkiye held in 2012. Previous studies have found publication rates of presentations in congresses in different disciplines, such as rheumatology, dermatology, general surgery, radiology, pediatric psychiatry, orthopedics, plastic surgery and urology, in Turkiye to be ranged between 5.7\% and 29.5\%
$(8,9,10,11,12,13,14)$. In this study, we identified that $28.3 \%$ of the presentations at the $1^{\text {st }}$ Congress of the Society of Urological Surgery in Turkiye were later published in PubMed-indexed journals. This rate is higher than in most of the studies in Turkiye. For big international urology organizations, this rate appears to vary from $29.8 \%$ to $61.6 \%$ for current meetings $(3,4,5,6,7)$. Though the publication rate of presentations at the 2012 Urological Surgery Congress is slightly lower compared to international meetings, the mean number of citations per publication of 5.65 is an important point. Publications originating from this congress received a total of 447 citations, forming a significant contribution to the literature.

Large differences may be encountered in presentation publication rates for congresses in different years held by the same urology organizations. For example, the publication rate of presentations at ESPU meetings from 2003 to 2010 varied from $36 \%$ to $63 \%$ (3). Similarly, the publication rate for the 2000 EAU meeting was $28.2 \%$, while for 2001 this rate increased to $71.8 \%$ (7). Among the reasons for this, we believe that causes such as different reviewers within the peer review process in different years and variations in presentation numbers taken for assessment through the years play a role. Scherer et al. (15) showed that the majority of presentations became publications within 5 years. Moving from this information, we only included congress data for the year 2012 in this study based on the time necessary for publication.

Autorino et al. (16) investigated EAU meetings in 2000-2001 and identified that $75 \%$ of the published presentations were published in journals with impact factor above 1. The mean impact factor of these journals was 1.95. The authors considered that this relatively low impact factor was due to the generally low impact factor of urology journals in general (16). In our study, the majority of journals were urology journals (69.6\%); the mean impact factor was 1.55 with $59.4 \%$ of journals with impact factor above 1 . 
While the number of presentations at meetings of organizations like the EAU reach 700 (7), the total number of presentations in our study was 279 . The need for reviewers to make decisions about many abstracts in insufficient time is a serious obstacle to appropriate evaluation (17). We believe that it is necessary to consider this fact, as it is a parameter that may affect the publication rates.

Experimental/laboratory studies require careful study and planning and so are valuable scientifically for publications; thus, they have high publication rates. Within clinical studies, prospective studies have higher rates of later publication compared to retrospective studies (16). In our study, prospective (31.5\%) and experimental/laboratory studies (40\%) had higher publication rates than retrospective studies $(24.5 \%)$, though this difference was not found to be statistically significant $(p=0.172)$.

There are many reasons why studies do not get published. It has been shown that studies reporting positive results were more likely to be published (18). Another study observed that reasons such as having insufficient time to complete the manuscript, thoughts that journals would not be interested in the paper and problems experienced with co-authors were obstacles to publication (19).

There are differences between the peer review process applied for choosing presentations for scientific meetings and the peer review process for acceptance to an indexed journal. Some research valuable for presentation may be insufficient for journal publication (20). It is thought that travel incentives given to assistants to present at some congresses but not given to produce publications are an obstacle to production of publications (21). In spite of this, though the majority of presentations accepted at congresses are not published, the publication rates are higher than the number of rejected presentations (22).

\section{Study Limitations}

A limitation of our study is that we did not investigate the rejected presentations. Reaching authors of presentations that were not published for survey studies will make it easier to investigate factors affecting transformation of presentations to publications in more depth. Additionally, considering that screening of internet-based databases is insufficient to reach nationally indexed journals, we only investigated the PubMed database publications. Although we conducted a thorough work for searching publications, still we might had errors caused by changes in the title and author names. Our study only investigated publications from a single congress. We believe that future studies with longer duration of evaluation will provide more homogenous results.

\section{Conclusion}

The publication rate of presentations at the Congress of the $1^{\text {st }}$ Society of Urological Surgery in Turkiye was higher than most national congresses in different disciplines, but lower than many international congresses in the field of urology. Future studies investigating congress data from several consecutive years will provide clearer results.

\section{Ethics}

Ethics Committe Approval: Our study was completed in accordance with the Declaration of Helsinki, with no ethics committee permission necessary for screening of publications.

Informed Consent: Not applicable.

Peer-review: Externally peer-reviewed.

\section{Authorship Contributions}

Concept: M.Y., T.I., A.T., Design: M.Y., T.I., A.T., Data Collection or Processing: M.Y., K.K., H.A., Analysis or Interpretation: M.Y., K.K., T.i., Literature Search: M.Y., K.K., T.i., A.T., H.A., Writing: M.Y., K.K., T.i.

Conflict of Interest: No conflict of interest was declared by the authors.

Financial Disclosure: The authors declared that this study received no financial support.

\section{References}

1. Hoag CC, Elterman DS, Macneily AE. Abstracts presented at the American Urological Association Annual Meeting: determinants of subsequent peer reviewed publication. J Urol 2006;176:2624-2629.

2. Van der Steen LP, Hage JJ, Loonen MP, Kon M. Full publication of papers presented at the 1995 through 1999 European Association of Plastic Surgeons annual scientific meetings: a systemic bibliometric analysis. Plast Reconstr Surg 2004;114:113-120.

3. Castagnetti M, Subramaniam R, El-Ghoneimi A. Abstracts presented at the European Society for Pediatric Urology (ESPU) meetings(2003-2010): Characteristics and outcome. J Pediatr Urol 2014;10:355-360.

4. Yoon PD, Chalasani V, Woo HH. Conversion rates of abstracts presented at the Urological Society of Australia and New Zealand (USANZ) Annual Scientific Meeting into full-text journal articles. BJU Int 2012;110:485-489.

5. Smith WA, Cancel OV, Tseng TY, Sultan S, Vieweg J, Dahm P. Factors associated with the full publication of studies presented in abstract form at the annual meeting of the American Urological Association. J Urol 2007;177:1084-1089.

6. Cartwright R, Khoo AK, Cardozo L. Publish or be damned? The fate of abstracts presented at the International Continence Society Meeting 2003. Neurourol Urodyn 2007;26:154-157.

7. Autorino R, Quarto G, Di Lorenzo G, De Sio M, Damiano R. Are abstracts presented at the EAU meeting followed by publication in peer-reviewed journals? A critical analysis. Eur Urol 2007;51:833-840.

8. Kalyoncu U, Çınar M, Demirağ MD, Yılmaz S, Erdem H, Kiraz S, Pay S, Ertenli i, Dinç A. Ulusal Romatoloji Kongrelerinde sunulan bildirilerin irdelenmesi: Neredeyiz? RAED Dergisi 2011;3:6-10. 
9. Özyurt S, Kaptanoğlu AF. 2004-2008 yılları arasında iki yılda bir yapılan ulusal dermatoloji kongrelerinde sunulan özetlerin yayınlanma oranları Dermatoz 2012;3:7-11.

10. Kabay B, Teke Z, Erbiş H, Koçgil G, Tekin K, Erdem E. Ulusal cerrahi kongrelerinde sunulan bildirilerin uluslararası yayına dönüşme oranları Ulus Cerrahi Derg 2005;21:130-134.

11. Seçil M, Uçar G, Sentürk C, Karasu S, Dicle O. Publication rates of scientific presentations in Turkish national radiology congresses. Diagn Interv Radiol 2005:11:69-73.

12. Mutlu C, Kaya Mutlu E, Kılıçoğlu AG, Yorbık Ö. From poster presentation to publication: National Congress of Child and Adolescent Psychiatry. Arch Neuropsychiatr 2015;52:111-116.

13. Ersoy B. What is the Ultimate Fate of Presented Abstracts? Conversion Rates of Presentations to International Publications from the 31st National Congress of Plastic, Reconstructive, and Aesthetic Surgery. Turk J Plast Surg 2016;24:8-18.

14. Kocaaslan R, Kayali Y, Tok A, Tepeler A. Publication rates of full-text journal articles converted from abstracts presented during the 22(nd) Turkish National Urology Congress. Turk J Urol 2016;42:16-20.

15. Scherer RW, Dickersin K, Langenberg P. Full publication of results initially presented in abstracts. A meta-analysis. JAMA 1994;272:158-162.
16. Autorino R, Quarto G, Di Lorenzo G, De Sio M, Damiano R. Are abstracts presented at the EAU meeting followed by publication in peer-reviewed journals? A critical analysis. Eur Urol 2007;51:833-840.

17. Relman AS. News reports of medical meetings: how reliable are abstracts? N Engl J Med 1980;303:277-278.

18. De Bellefeuille C, Morrison CA, Tannock IF. The fate of abstracts submitted to a cancer meeting: factors which influence presentation and subsequent publication. Ann Oncol 1992;3:187-191.

19. Weber EJ, Callaham ML, Wears RL, Barton C, Young G. Unpublished research from a medical specialty meeting: why investigators fail to publish. JAMA 1998;280:257-259.

20. Autorino $R$, Quarto G, Di Lorenzo G, Giugliano $F$, Quattrone $C$, Neri $F$, De Domenico R, Sorrentino D, Mordente S, Damiano R, De Sio M. What happens to the abstracts presented at the Societè Internationale d'Urologie meeting? Urology 2008;7q1:367-371.

21. Dickersin $\mathrm{K}, \mathrm{Min} \mathrm{YI}, \mathrm{Meinert} \mathrm{CL}$. Factors influencing publication of research results: Follow-up of applications submitted to two institutional review boards. JAMA 1992;267:374-378.

22. Varghese RA, Chang J, Miyanji F, Reilly CW, Mulpuri K. Publication of abstracts submitted to the annual meeting of the Pediatric Orthopaedic Society of North America: is there a difference between accepted versus rejected abstracts? J Pediatr Orthop 2011;31:334-340. 